\title{
PIGA wt Allele
}

National Cancer Institute

\section{Source}

National Cancer Institute. PIGA wt Allele. NCI Thesaurus. Code C95926.

Human PIGA wild-type allele is located in the vicinity of Xp22.1 and is approximately $16 \mathrm{~kb}$ in length. This allele, which encodes phosphatidylinositol $\mathrm{N}$-acetylg lucosaminyltransferase subunit A protein, plays a role in the modulation of protein lipidation. Mutation of the gene is associated with paroxysmal nocturnal hemog lobinuria. 